\title{
PENGARUH Paenibacillus polymyxa DAN Pseudomonas fluorescens DALAM MOLASE TERHADAP KETERJADIAN PENYAKIT BULAI (Peronosclerospora maydis L.) PADA TANAMAN JAGUNG MANIS
}

\author{
Hardy Muhammad Ridwan, Muhammad Nurdin \& Suskandini Ratih D. \\ Jurusan Agroteknologi, Fakultas Pertanian Universitas Lampung \\ J1.Prof. Soemantri Brodjonegoro, No.1, Bandar Lampung 35145 \\ E-mail: hm.ridwan07@yahoo.co.id
}

\begin{abstract}
ABSTRAK
Salah satu kendala yang dihadapi dalam budidaya jagung manis yaitu penyakit bulai. Penelitian ini bertujuan untuk mengetahui pengaruh Paenibacillus polymyxa atau Pseudomonas fluorescens dalam molase terhadap keterjadian penyakit bulai (Peronosclerospora maydis), pertumbuhan dan produksi jagung manis. Percobaan disusun dalam Rancangan Acak Lengkap (RAL) dengan 4 perlakuan dan 5 ulangan sehingga jumlah unit percobaan yaitu 20. Perlakuan yang diujikan adalah Paenibacillus polymyxa yang diformulasikan dalam molase, Pseudomonas fluorescens yang diformulasikan dalam molase, tanpa bakteri, dan fungisida berbahan aktif metalaksil. Setiap ulangan terdapat 4 tanaman. Data dianalisis dengan menggunakan analisis ragam dan dilanjutkan dengan uji BNT dengan taraf kepercayaan 95\%. Hasil penelitian menunjukkan bahwa P. polymyxa dalam molase lebih efektif dalam menekan keterjadian penyakit, meningkatkan tinggi tanaman dan bobot tongkol dibandingkan dengan perlakuan lainnya.
\end{abstract}

Kata kunci: Jagung manis, molase, Paenibacillus polymyxa, Pseudomonas fluorescens.

\section{PENDAHULUAN}

Jagung manis (Zea mays var. saccarata) adalah tanaman pangan yang kebutuhan setiap tahunnya meningkat sehubungan dengan pertambahan penduduk yang senang mengkonsumsinya. Jagung manis selain dapat dimanfaatkan sebagai bahan pangan juga digunakan untuk bahan baku industri gula jagung (Bakhri, 2007).

Produksi jagung manis di Indonesia pada tahun 2013 mengalami penurunan dibandingkan dengan produksi jagung manis pada tahun 2012 (Badan Pusat Statistik, 2014). Produksi jagung manis pada tahun 2013 adalah 18.506.287 ton sedangkan pada tahun 2012 adalah 19.377 .030 ton.

Salah satu kendala dalam budidaya tanaman jagung termasuk jagung manis adalah penyakit bulai yang disebabkan oleh jamur Peronosclerospora maydis. Tanaman jagung yang terserang $P$. maydis mengalami penurunan produksi sebesar $80 \%-100 \%$. Hal ini dikarenakan tanaman jagung manis yang terserang $P$. maydis tidak dapat menghasilkan biji (Soenartiningsih, 2010).
Pada umumnya jagung ditanam sepanjang waktu tetapi tanaman jagung rentan terserang $P$. maydis sehingga sumber inokulum selalu tersedia di areal pertanaman. Oleh karena itu, penyakit bulai dapat dikendalikan dengan penggunaan kultivar tahan, tanam serempak, sanitasi kebun, rotasi tanaman, eradikasi, dan penggunaan fungisida (Badan Litbang Pertanian, 2012). Fungisida merupakan cara pengendalian yang paling umum dilakukan oleh petani. Penggunaan fungisida berbahan aktif metalaksil merupakan pengendalian yang dilakukan petani untuk mengendalikan penyakit bulai jagung. Namun, keefektifan fungisida berbahan aktif metalaksil mengalami penurunan. Peningkatan dosis fungisida bahkan dapat meningkatkan keterjadian penyakit bulai. Hal ini dikarenakan P. maydis mengalami resistensi (Surtikanti, 2012). Oleh karena itu, perlu dicari pengendalian alternatif untuk mengendalikan penyakit bulai pada tanaman jagung.

Salah satu alternatif pengendalian penyakit bulai jagung yang ingin dilakukan adalah penggunaan mikroorganisme berupa bakteri Paenibacillus polymyxa atau Pseudomonas fluorescens yang diformulasikan dalam bentuk cair dengan bahan pembawa berupa molase. Larutan dapat mengandung 
unsur hara makro, mikro, atau mengandung mikroorganisme yang berpotensi sebagai perombak bahan organik, perangsang pertumbuhan, dan agen pengendali hama dan penyakit tanaman sehingga baik digunakan sebagai dekomposer, pupuk hayati, atau pestisida organik (Purwasasmita, 2009). Formulasi cair yang mengandung agen hayati dibuat dengan tujuan untuk memperpanjang kemampuan agen hayati bertahan hidup, untuk memudahkan aplikasi, dan untuk penyimpanan jangka panjang.

Agen hayati yang digunakan dapat berupa $P$. polymyxa. P. polymyxa menghasilkan antibiotik serta dapat berperan sebagai kompetitor terhadap unsur hara bagi patogen tanaman (Sutariati (2006) dalam Siregar et al., 2007). Selain itu dapat digunakan juga Pseudomonas fluorescens yaitu bakteri yang mampu menghasilkan antibiotik Penazine 1-Carboxilic Acid (PCA) yang berfungsi untuk menghambat pertumbuhan jamur (Talanca, 2002). Berdasarkan kemampuan bakteri tersebut maka mikroorganisme berupa $P$. polymyxa dan $P$. fluorescens diharapkan dapat mengurangi pertumbuhan $P$. maydis.

Penelitian ini bertujuan untuk mengetahui pengaruh $P$. polymyxa atau $P$. fluorescens terhadap keterjadian penyakit bulai (P. maydis), pertumbuhan, dan produksi jagung manis.

\section{BAHAN DAN METODE}

Penelitian dilaksanakan di Laboratorium Lapang Terpadu dan di Laboratorium Penyakit Tumbuhan, Fakultas Pertanian, Universtitas Lampung dari Desember 2013 sampai dengan Februari 2014.

Benih yang digunakan adalah benih jagung manis kultivar Bonanza F1 yang rentan terhadap penyakit bulai. Penelitian disusun dalan rancangan acak lengkap dengan 5 ulangan dan setiap ulangan terdiri dari 4 tanaman sehingga setiap satu perlakuan sebanyak 20 unit tanaman percobaan. Data dianalisis dengan menggunakan sidik ragam dan dilanjutkan dengan uji BNT dengan taraf kepercayaan $95 \%$. Perlakuan terdiri atas $P$. polymyxa yang diformulasikan dalam molase, $P$. fluorescens yang diformulasikan dalam molase, tanpa bakteri, dan fungisida berbahan aktif metalaksil.

Tanaman uji yang digunakan adalah tanaman jagung manis Bonanza F1 yang rentan terhadap serangan patogen $P$. maydis. Benih jagung ditanam pada lahan yang telah dibersihkan dari gulma dan tanah diolah sampai gembur. Benih ditanam 1 butir per lubang dengan jarak tanam $75 \mathrm{~cm} \times 25 \mathrm{~cm}$. Pemeliharaan tanaman yang dilakukan berupa pemupukan, penyiraman, dan pengendalian gulma. Dosis pupuk yang digunakan yaitu urea $300 \mathrm{~kg} \mathrm{ha}^{-1}, \mathrm{KCl} 100 \mathrm{~kg} \mathrm{ha}^{-1}$, dan SP-36 $100 \mathrm{~kg}$ $\mathrm{ha}^{-1}$.

P. polymyxa dan $P$. fluorescens diperbanyak pada media Nutrient Agar (18 g per liter air). Sejarah ketersediaan awal isolat $P$. polymyxa diperoleh dari BBPOPT Jatisari yaitu hasil isolasi dari tanah rizosfer tanaman padi dan P. fluorescens diperoleh dari hasil isolasi tanah rizosfer pertanaman kedelai di Natar.

Bahan yang digunakan yaitu molase dan isolat $P$. polymyxa atau $P$. fluorescens. Formulasi cair dibuat dengan mensuspensikan satu cawan petri bakteri $P$. polymyxa berumur 5 hari inkubasi atau $P$. fluorescens berumur 5 hari inkubasi dalam akuades sebanyak 100 $\mathrm{ml}$. Selanjutnya suspensi bakteri ini ditambahkan dalam $20 \mathrm{ml}$ molase $1 \%$ (artinya $0,1 \mathrm{~g}$ molase kental dalam 10 ml air).

$P$. polymyxa atau $P$. fluorescens yang diformulasikan dalam molase digunakan sebagai perendam benih selama 12 jam dan penyemprotan daun corong jagung berumur 5 hari setelah tanam. Formulasi yang digunakan untuk perendaman dan penyemprotan jagung merupakan formulasi yang sama yaitu suspensi satu cawan petri bakteri $P$. polymyxa berumur 5 hari inkubasi atau $P$. fluorescens berumur 5 hari inkubasi dalam akuades sebanyak $100 \mathrm{ml}$. Selanjutnya suspensi bakteri ini ditambahkan dalam $20 \mathrm{ml}$ larutan molase. Pada saat aplikasi formulasi tersebut tidak perlu diencerkan lagi dengan air melainkan langsung diaplikasikan pada benih jagung manis dan daun corong jagung manis.

Tanaman jagung perlakuan tanpa bakteri yaitu tanaman jagung diinfeksi dengan bulai jagung dan tidak diberi agen hayati apapun. Tanaman jagung perlakuan fungisida berbahan aktif metalaksil berasal dari benih jagung manis yang direndam fungisida berbahan aktif metalaksil selama 12 jam dengan cara melarutkan fungisida berbahan aktif metalaksil sebanyak $5 \mathrm{ml}$ ke dalam akuades 1 liter.

Inokulum $P$. maydis diperoleh dengan cara mencacah daun jagung sebanyak $72 \mathrm{~g}$ yang menunjukkan serangan $P$. maydis kemudian direndam ke dalam 1 liter air yang telah dicampur dengan $5 \mathrm{~g}$ gula pasir selama 4 jam. Inokulasi tanaman jagung manis dilakukan pada saat 7 hari setelah tanam. Inokulasi P. maydis dilakukan dengan cara menyemprotkan air rendaman tersebut pada titik tumbuh tanaman jagung sebanyak $1 \mathrm{ml}$. Inokulasi dilakukan pada pukul 18.00 WIB. Inokulasi $P$. maydis dilakukan pada saat tanaman jagung manis berumur 7 hari setelah tanam.

Peubah yang diamati dalam penelitian adalah masa inkubasi, keterjadian penyakit, tinggi tanaman, dan bobot tongkol. Keterjadian penyakit dihitung dengan 
menggunakan rumus (Sekarsari et al., 2013) sebagai berikut:

$$
K P=\frac{n}{N} \times 100 \%
$$

Dengan KP adalah keterjadian penyakit, $\mathrm{n}$ adalah jumlah tanaman yang terserang, dan $\mathrm{N}$ adalah jumlah tanaman yang diamati.

\section{HASIL DAN PEMBAHASAN}

Gejala penyakit bulai pada tanaman jagung manis kultivar Bonanza F1 mulai terlihat pada saat 5 hari setelah inokulasi (hsi) P. maydis. Gejala awal penyakit bulai yaitu munculnya garis-garis kekuningan (klorosis) sejajar tulang daun kemudian klorosis menyebar di seluruh permukaan daun. Hasil penelitian menunjukkan bahwa aplikasi formulasi cair berupa molase berbahan aktif mikroorganisme berbeda nyata terhadap keterjadian penyakit pada saat 14 hari setelah inokulasi, tinggi tanaman, dan bobot tongkol, tetapi masa inkubasi tidak berpengaruh nyata (Tabel 1).

Perlakuan $P$. polymyxa dalam molase berpengaruh pada keterjadian penyakit saat 14 hari setelah inokulasi, tinggi tanaman, dan bobot tongkol. Aplikasi $P$. polymyxa dan molase mampu menekan keterjadian penyakit diduga disebabkan oleh antibiotik yang terkandung di dalam $P$. polymyxa serta molase yang berperan sebagai sumber nutrisi. $P$. polymyxa mengandung antibiotik Fusaricidin yang diduga mampu menghambat kehidupan $P$. maydis sebagai patogen penyebab bulai (Raza et al., 2008). Menurut Burges dan Jones (1998) dalam Hanudin dan Marwoto (2012), molase berperan sebagai sumber nutrisi sehingga $P$. polymyxa dapat bertahan hidup dengan memanfaatkan molase sebagai sumber nutrisi. Atas dasar itulah $P$. polymyxa mampu menekan $P$. maydis pada saat 7 hari setelah inokulasi.

Selain itu, $P$. polymyxa juga berpengaruh pada tinggi tanaman dan bobot tongkol disebabkan $P$. polymyxa diduga mampu menghasilkan auksin dan sitokinin, serta memfiksasi nitrogen (Timmusk (2003) dalam Siregar et al., 2007). Oleh karena itu, aplikasi $P$. polymyxa pada penelitian ini ternyata juga meningkatkan pertumbuhan tanaman jagung manis menjadi lebih tinggi dibandingkan dengan tanaman yang tanpa aplikasi $P$. polymyxa. Pertumbuhan tanaman jagung manis akibat adanya aplikasi $P$. polymyxa menyebabkan masih dapat menghasilkan tongkol dengan bobot tongkol 194,88 g. Hasil penelitian ini sejalan dengan Siregar et al. (2007) bahwa perendaman benih cabai dengan $P$. polymyxa dapat meningkatkan ketahanan tanaman cabai terhadap penyakit antraknosa.bahkan dapat memacu pertumbuhan tanaman cabai sehingga meningkatkan mutu fisik dan mutu fisiologis benih cabai yang dihasilkan.

P. fluorescens dalam molase berpengaruh pada keterjadian penyakit saat 14 hari setelah inokulasi, tinggi tanaman, dan bobot tongkol. Aplikasi P. fluorescens dan molase mampu menekan keterjadian penyakit diduga disebabkan oleh kandungan antibiotik yang dihasilkan oleh P. fluorescens. P. fluorescens mampu menghasilkan antibiotik Penazine 1-Carboxilic Acid (PCA) yang berfungsi untuk menekan pertumbuhan jamur (Talanca, 2002), serta kemampuan $P$. fluorescens yang mampu bertahan di tanaman jagung manis akibat adanya sumber nutrisi yang diperoleh dari molase. $P$. fluorescens umumnya digunakan untuk mengendalikan hawar daun bakteri pada tanaman padi yang telah dilakukan di Purwakarta (Ismail et al., 2011) yang terbukti efektif dalam mengendalikan penyakit karat

Tabel 1. Pengaruh perlakuan terhadap masa inkubasi, tinggi tanaman, keterjadian penyakit bulai, dan bobot tongkol pada tanaman jagung manis.

\begin{tabular}{lcccc}
\hline \multicolumn{1}{c}{ Perlakuan } & $\begin{array}{c}\text { Masa Inkubasi } \\
\text { (hari) }\end{array}$ & $\begin{array}{c}\text { Keterjadian Penyakit } \\
(\%)\end{array}$ & $\begin{array}{c}\text { Tinggi Tanaman } \\
(\mathrm{cm})\end{array}$ & $\begin{array}{c}\text { Bobot Tongkol } \\
(\mathrm{g})\end{array}$ \\
\hline P. polymyxa + molase & 10,50 & $15,00 \mathrm{~b}$ & $40,25 \mathrm{a}$ & $195 \mathrm{a}$ \\
P. fluorescens + molase & 10,60 & $10,00 \mathrm{~b}$ & $36,70 \mathrm{~b}$ & $139 \mathrm{~b}$ \\
Tanpa bakteri & 5,50 & $65,00 \mathrm{a}$ & $33,02 \mathrm{c}$ & $97 \mathrm{c}$ \\
Metalaksil & 9,60 & $10,00 \mathrm{~b}$ & $33,80 \mathrm{c}$ & $91 \mathrm{c}$ \\
\hline \multicolumn{1}{c}{ BNT 0,05 } & - & 21,85 & 1,96 & 0,09 \\
F-hitung & $2,73^{\text {th }}$ & $13,49^{*}$ & $25,20^{*}$ & $24,09^{*}$ \\
\hline
\end{tabular}

Keterangan: Nilai tengah yang diikuti dengan huruf yang sama pada kolom tidak berbeda berdasarkan uji BNT pada $\alpha=5 \%$. Angka dalam kurung merupakan nilai tengah hasil setelah dilakukan transformasi. 
daun yang disebabkan oleh jamur Puccinia polysora (Talanca, 2002).

Selain itu, aplikasi $P$. fluorescens mampu menghasilkan bobot tongkol yang lebih tinggi dibandingkan dengan tanpa perlakuan dan perlakuan fungisida berbahan aktif metalaksil. Menurut Weller (1988) dalam Soesanto (2010) P. fluorescens mampu memacu pertumbuhan tanaman dengan meningkatkan ketersediaan zat makanan dan mampu menghasilkan auksin sehingga meningkatkan pertumbuhan tanaman. Penelitian ini sejalan dengan Soesanto (2010) bahwa aplikasi $P$. fluorescens meningkatkan bobot buah tomat per tanaman.

Pada penelitian ini juga digunakan metalaksil sebagai pembanding. Hasil penelitian menunjukkan bahwa keterjadian penyakit bulai pada tanaman jagung manis yang diaplikasikan metalaksil tidak berpengaruh nyata dibandingkan dengan tanaman jagung manis yang diaplikasi $P$. polymyxa dan $P$. fluorescens. Hal ini menunjukkan bahwa fungisida sintetik berbahan aktif metalaksil kurang efektif dalam mengendalikan penyakit bulai pada tanaman jagung manis.

\section{KESIMPULAN}

Berdasarkan hasil penelitian maka dapat disimpulkan bahwa perlakuan $P$. polymyxa dan molase paling efektif dalam menekan keterjadian penyakit, meningkatkan tinggi tanaman, dan bobot tongkol.

\section{DAFTAR PUSTAKA}

\section{Badan Litbang Pertanian. 2012. Penyakit Bulai pada} Tanaman Jagung dan Teknik Pengendaliannya. Sinartani, 25-31 Januari 2012. hlm.13-16.

Bakhri, S. 2007. Budidaya jagung dengan konsep pengelolaan tanaman terpadu (PTT). Balai Pengkajian Teknologi Pertanian. Sulawesi Tengah. $17 \mathrm{hlm}$.

Biro Pusat Statistik. 2014. Tabel Luas PanenProduktivitas- Produksi Tanaman Jagung Provinsi Indonesia. http://www.bps.go.id/ tnmn_pgn.php. Diakses pada tanggal : 21 April 2014.
Hanudin dan B. Marwoto. 2012. Penyakit karat putih pada krisan dan upaya pengendaliannya. Jurnal Litbang Pertanian. 31(2): 51-57.

Ismail, N., L.A. Taulu, dan Bahtiar. 2011. Potensi Corynebacterium sebagai pengendali penyakit hawar daun bakteri pada Tanaman Padi. Seminar Nasional Serealia 2011, hlm. 459-465.

Purwasasmita, M. 2009. Pemanfaatan Larutan MOL. http://riefarm.blogspot.com/. Diakses pada tanggal : 25 Mei 2014.

Raza W., W.Young, dan Q.R. Shen. 2008. Paenibacillus polymyxa: antibiotics hydrolitic enzymes and hazzard assessment. Journal of Plant Pathology. 90(3): 419-430.

Sekarsari, R.A., J. Prasetyo, dan T. Maryono. 2013. Pengaruh beberapa fungisida nabati terhadap keterjadian penyakit bulai pada tanaman jagung manis (Zea mays saccharata). Jurnal Agrotek Tropika. 1(1): 98-101.

Siregar, A.N., S. Ilyas, D. Fardiaz, E. Murniati, dan E. Wiyono. 2007. Penggunaan agens biokontrol Bacillus polymyxa dan Trichoderma harzianum untuk meningkatkan mutu benih cabai dan pengendalian penyakit antraknosa. Jurnal Penyuluhan Pertanian. 2(2): 105-114.

Soenartiningsih. 2010. Perkembangan penyakit bulai (Peronosclerospora maydis) pada jagung tahun 2008-2009 di Kabupaten Blitar. Prosiding Seminar Ilmiah dan Pertemuan Tahunan PEJ dan PFJ XX Komisariat Daerah Sulawesi Selatan. hlm. 100-106.

Soesanto L., E. Mugiastuti, dan R.F. Rahayuniati. 2010. Kajian mekanisme antagonis Pseudomonas fluorescens $\mathrm{P} 60$ terhadap Fusarium oxysporum F.SP. Lycopersici pada tanaman tomat in vivo. Jurnal HPT Tropika. 10(2): 108-115.

Surtikanti. 2012. Penyakit bulai pada tanaman jagung. Superman: Suara Perlindungan Tanaman. 2(1): 41-48.

Talanca,A.H. 2002. Peranan beberapa mikroorganisme untuk pengendalian penyakit jagung. Prosiding Seminar Ilmiah dan Pertemuan Tahunan PEI, PFI dan HPTI XV Sul-Sel. hlm.17-21. 